\title{
Mediating Role of School Attachment in the Relationship between Perceived Stress and School Satisfaction
}

\author{
Tuncay Oral, PhD
}

Pamukkale University, Turkey

\section{Doi:10.19044/ejes.v7no3a11 URL:http://dx.doi.org/10.19044/ejes.v7no3a11}

\begin{abstract}
The purpose of this study is to test the mediating role of school attachment in the relationship between perceived stress and school satisfaction in secondary school students. In the study, the Perceived Stress Scale in Children, Brief Adolescents' Subjective Well-Being in School Scale, and the School Attachment Scale for children and adolescents were applied to 538 students (258 girls and 280 boys) who were educated in different secondary schools in Turkey. The data were tested using Pearson moments multiplication correlation coefficient and structural equation model analysis. Research results have shown that school attachment plays a fully mediating role in the relationship between perceived stress and school satisfaction in secondary school students. In other words, stress's predictability of school satisfaction has been eliminated by the inclusion of the mediatory variable of school attachment into the structural equation model. This result has been discussed in light of theoretical and empirical data.
\end{abstract}

Keywords: Stress, School Attachment, School Satisfaction.

\section{Introduction}

Stress is the negative emotions and beliefs that a person experiences when they feel unable to cope with the wishes of the environment they are in (Aronson, Wilson, \& Akert, 2012). Stress can also be caused by the threat and difficulty of physical and spiritual boundaries along with features such as extreme tension, inability to relax, and restlessness (Lovibond \& Lovibond, 1995). Stress has become a term that is conceptually expressed in our everyday lives without question and has evolved into a concept that significantly affects human life. Stress threshold is the lowest level of arousal in which an individual perceives an internal or external stimulant as a threat that will result in a stress response. So while one condition or a situation may be stressful for one of the two people, it may not be stressful for the other. In other words, the 
resulting stress response is the result of an internal evaluation of how one perceives the source of stress (Uluğ, 2010). Stress is not just an adult-related concept (Wible, 2013). Children and adolescents can experience stress just like adults. This stress that children and adolescents experience can result from a variety of situations, such as achieving academic success in school, making and maintaining friends, and managing the expectations of parents and teachers (APA, 2009). However, it is emphasized that children and adolescents are more vulnerable to stress if they have one or more of the conditions such as problem in the family economy, nutrition and sleep problems, lack of adequate social support from parents and predisposition to conflict and crime in the family environment (Terzian, Moore, \& Nguyen, 2010). In some sources, children receiving "do it" messages from their parents or teachers too often, being overfilled with homework and different programs, losing their sense of security, and being unable to spend qualified time with their parents have been cited as sources of stress (Korkut-Owen, 2015). A child's response to stress may not resemble an adult's. There may also be a difference in stress symptoms according to their age, such as the social, emotional, and biological development of children. Preschool children often return to infancy behaviors such as crying, having problems eating and sleeping, being aggressive or timid, or losing control of their bladder. Primary and secondary school-age children show stress through the loss of appetite, abdominal pains, abstinence from activities, sadness, depression, whining (Longo, 2000). According to O'Rourke and Worzbyt (1996), having problems with school attendance and focusing, having conflicts with teachers, having school-related concerns, acting aggressively in peer-to-peer relationships can in some cases be symptoms of stress. Individual experiences and assessments related to the school environment in which a significant proportion of these stress symptoms are experienced are associated with the overall quality of life of the students (Huebner \& Gilman, 2006).

School is an important developmental environment where adolescents spend a large part of their time. Although it is stated that adolescents' schoolrelated lives and their long-term psychological development are related (Huebner, 2010), there are only a few studies that examine school satisfaction. School satisfaction is the cognitive assessment of school life by the student's own standards in various areas related to school (learning environment, student-teacher relationship) (Baker, Dilly, Aupperlee, \& Patil, 2003). School satisfaction is associated with many areas of compliance, such as student behavior at school, academic achievement, and meeting basic psychological needs at school (Huebner \& Gilman, 2006). A study in America calculated scores on some of the sub-dimensions of students' life satisfaction (family, friends, environment, selfness, and school). When these scores were examined, it was found that the lowest score belonged to school satisfaction 
(Huebner et al., 2000). A similar study found that approximately $25 \%$ of students had school dissatisfaction and $10 \%$ of their experience was terrible. Given that school satisfaction levels drop as children enter puberty (Proctor, Linley, \& Maltby, 2010; Suldo, Riley, \& Shaffer, 2006), it has been concluded that secondary school level can be a significant source of school dissatisfaction for a large number of students. Among adolescents, it was concluded that student-teacher relationships are a stronger variable in predicting school satisfaction than family and friend relationships (DeSantis-King, Huebner, Suldo, \& Valois, 2006). A study conducted in four countries in Europe found that the first two of the most important concepts affecting students' school satisfaction were the environmental justice/equality at school and the support of the teachers (Samdal, Nutbeam, Wold, \& Kannas, 1998). When the literature was examined, it was seen that the concept of school satisfaction is in positive directional relationship with variables such as happiness (Schnettler et al., 2015), positive social behavior (Hilooğlu \& CenksevenÖnder, 2010), self-esteem (Karatzias, Power, Flemming, Lennan, \& Swanson, 2002), academic success (Bacete, Perrin, Schneider, \& Blanchard, 2014; Hampden, Thompson, \& Galindo, 2017) and school climate (Varela et al., 2018).

Although school life is an important variable closely related to the life satisfaction of the students (Özdemir \& Koruklu, 2013), it is also a process that includes many sources of stress, including anxiety of tests and failure and conflicts created by relationships with peers (Santrock, 2012). One of the most important variables identified in the literature is attachment, which protects the individual from the negative effects of such stress-inducing experiences in adolescence as in other periods of life. Developed by Bowlby (1969), the concept is defined as the intense emotional bond that the individual develops for people who make sense for himself/herself. According to Bowlby (1969, 1973), the infant develops schemes that include basic expectations and understanding of the accessibility of others in the event of need, in line with the quality of the relationships he/she has established with others as a result of his/her early life experiences. Later in life, this basic understanding determines the patterns of behavior that the individual will refer to in their relations with others. As such, children whose needs are met and a safe environment is created by the primary attachment figure can apply to the source of attachment for help and support in stressful situations and make healthy decisions in terms of development by taking risks when necessary, with the feeling of trust resulting from the healthy psycho-social bond established with their primary attachment figure. On the other hand, based on such positive interactions, children who are deprived of the cognitive and emotional scheme that others are trustworthy and that themselves are valuable, do not trust others and do not benefit from the psycho-social, physical support and comfort that can be 
provided from the outside against the sources of stress. School attachment, a continuation of children's early attachment relationships, plays a very functional role in children's lives with its cognitive, emotional, and behavioral dimensions (Fredricks, Blumenfeld, \& Paris, 2004). In the process of development, it is a very strong psychological need for adolescents to experience different attachment relationships and gain a sense of belonging (Osterman, 2000). Schools are considered to be an important socializing environment that ensures such relationships of attachment (Catalano, Haggerty, Oesterle, Fleming, \& Hawkins, 2004). Attachment to teachers and other adults in this respect is a very important developmental process that continues to have an effect in later life as a continuation of initial attachment relationships (Bergin \& Bergin, 2009). In this respect, the concept of school attachment as a form of attachment is related to functions such as a sense of belonging, emotional attachment, and satisfaction from school life (Ueno, 2009). Studies show that students with low levels of school attachment behave more aggressively towards their peers and experience school rage. General life satisfaction, psychological stability, and positive social behavior increase in students with high levels of school attachment (Ashley, Ennis, \& OwusuAnsah, 2012; Savi-Çakar \& Karataş, 2017).

\section{The present study}

According to the results of the literature review, when the stress levels increase, secondary school students, stay away from activities in the school environment, cannot adapt to the school, and feel anxiety and sadness about the school (Longo, 2000). This can significantly lower students' school satisfaction. In addition, the students who suffer from stress have difficulty adapting to the environment as a result of the threat of physical and spiritual boundaries. When the literature is examined, one of the concepts that can eliminate the effect of stress on reducing school satisfaction is thought to be school attachment. As a matter of fact, it is stated that the students who have school attachment have decreased mental distress and increased feelings of school safety, positive emotions and school satisfaction (Baker et al., 2003; Katja, Paivi, Marja-Terttu, \& Pakka, 2002; Tian, Liu, Huang, \& Huebner, 2013). For these reasons, school attachment is thought to reduce (partial mediation) or eliminate (full mediation) the possible negative relationship between stress and school satisfaction. Although there are several studies in the literature on the concepts of stress, school satisfaction, and school attachment, there is no study in which these three variables are examined simultaneously with the structural equation model within the framework of available sources. In this study, it is particularly important to examine whether school attachment plays a mediating role in the relationship between stress and school satisfaction. In light of all these assessments, this study sought answers 
to the research question, which was determined as "Is there a mediating role of school attachment in the relationship between stress and school satisfaction in secondary school students?"

\section{Method}

\section{Participants}

The participants of the study consist of 538 students who continue their education in 5 different secondary schools in Denizli/Turkey city center. After obtaining the required permits from school administrators and teachers, the researcher provided data collection tools to students who voluntarily agreed to participate in the study. During this period, analyses were carried out on 538 scales due to some of the 550 scales presented by the researcher to the students being severely incomplete. There is no ethnic difference between the participants. 280 of the students were male $(52.0 \%)$ and $258(48.0 \%)$ were female. In terms of their age, $135(25.1 \%)$ of the children are 9 years old, 139 $(25.8 \%)$ are 10 years old, $111(20.6 \%)$ are 11 years old, $59(11.0 \%)$ are 12 years old, $62(11.5 \%)$ are 13 years old and $32(5.9 \%)$ are 14 years old. The average age of children is 10.76 and the standard deviation of their age is 1.52.

\section{Data Collection Tools \\ School Attachment Scale}

The School Attachment Scale, developed by Hill (2006) and adapted to the Turkish language by Savi (2011), was used to determine the students' school attachment. The adaptation study was carried out on 708 students who were studying in 3-4-5-6-7-8th grades of primary schools and whose ages ranged between 9-14. The scale consists of 13 items. There are three subdimensions on the scale: (Example item: I am proud to be at this school), teacher attachment (Example item: I like my teachers), and friend attachment (Example item: I am proud with my friends). The scale is a 5-point Likert-type scale. The individual marks one of the options of 1 (definitely yes), 2 (yes), 3 (maybe), 4 (no), and 5 (definitely no) to indicate how suitable the statement he/she read is for him/her. The scores that can be obtained from the scale vary between 13 and 65 points. The high score obtained from the scale indicates that school attachment is high. Exploratory factor analysis was performed to determine the validity of the scale, and it was reported that scale materials were collected under three factors that accounted for $59 \%$ of the total variance. In another study, Savi-Çakar and Karataş (2017) used confirmatory factor analysis was performed to determine the validity of the School Attachment Scale. Confirmatory factor analysis was performed for the scale and fit indices were calculated as $\chi 2 / \mathrm{df}=2.98, \mathrm{p}<.001, \mathrm{RMSEA}=.08, \mathrm{SRMR}=.06, \mathrm{GFI}=$ $.90, \mathrm{AGFI}=.85, \mathrm{NFI}=.92, \mathrm{CFI}=.94$. The internal consistency coefficient of Cronbach Alpha calculated for all items of the scale was 0.84 and the test- 
retest reliability coefficient was 0.85 . The internal consistency coefficients obtained for the sub-dimensions of the scale were found 0.82 for the subdimension of school attachment, 0.74 for the sub-dimension of teacher attachment and 0.71 for the sub-dimension of friend attachment (Savi, 2011).

\section{Brief Adolescents' Subjective Well-Being in School Scale (BASWBSS)}

Brief Adolescents' Subjective well-Being in School Scale, developed by Tian, Wang and Huebner (2015) and adapted to Turkish by Özdemir and Sağkal (2016), was used to determine students' school satisfaction. The adaptation study was carried out on 336 students who were between 10-14 years of age in the 5-6-7 and 8th grades of the schools. The scale consists of two sub-dimensions: school satisfaction and school effect. In this study, school satisfaction sub-dimension was used. The School Satisfaction dimension consists of 8 items related to success, school management, teacher-student relations, peer relations, teaching and academic learning (Example item: I perform well in my school). The scale is a 6-point Likert-type scale. The individual can give answers ranging from 1 (strongly disagree) to 6 (strongly agree) to indicate how appropriate the statement he/she read is for him/her. The scores that can be obtained from the scale vary between 8 and 48 points. The high score obtained from the scale indicates that school satisfaction is high. Confirmatory factor analysis was performed to determine the validity of

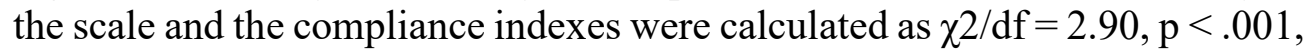
RMSEA $=.08$, SRMR $=.05, \mathrm{GFI}=.94, \mathrm{AGFI}=.90, \mathrm{NFI}=.96, \mathrm{CFI}=.98$. Cronbach Alpha internal consistency coefficient calculated for all items of the scale was found to be .84 and .93 for school satisfaction sub-dimension (Özdemir \& Sağkal, 2016).

\section{Perceived Stress Scale in Children}

Perceived Stress Scale in Children, developed by Snoeren and Hoefnagels (2014), adapted to Turkish by Oral and Ersan (2017), was used to determine the perceived stresses of students. The adaptation study was conducted with 380 students ranging in age from 8 to 11 . The scale is onedimensional and consists of 9 items. The scale includes items such as "in the last week, find it hard to calm down" and "feel like there was a lot to do and too little time". The scale is a 4-point Likert-type scale. The individual points to one of the options 1 (almost never), 2 (sometimes), 3 (often), and 4 (very often) to indicate how appropriate the statement he/she read is for him/her. The scores that can be obtained from the scale vary between 9 and 36 points. The high score obtained from the scale indicates that the perceived stress is high. Confirmatory factor analysis was performed within the scope of the validity studies of the scale and compliance indexes were calculated as $\chi^{2 / \mathrm{df}}$ $=1.58, \mathrm{p}>.001, \mathrm{RMSEA}=.04, \mathrm{SRMR}=.03, \mathrm{GFI}=98, \mathrm{AGFI}=.96, \mathrm{CFI}=$ 
97. The Cronbach Alpha reliability coefficient of the scale was found to be .76 and the test-retest reliability coefficient was found to be.71 (Oral \& Ersan, 2017).

\section{Data Analysis}

Before the analysis of the data, the coefficients of kurtosis and skewness were examined to determine whether they exhibited a normal distribution (see table 1). It has been recognized that the values of kurtosis and skewness for dependent, independent, and mediator variables are between -2 and +2 and exhibits a normal distribution (Morgan, Leech, Gloeckner, \& Barrett, 2004; Nielsen, et al., 2017). Then the descriptive statistics of the variables and the relations between the variables were presented. Subsequently, two-stage structural equation modeling was carried out in line with Kline's (2011) recommendations. This modeling is considered to be one of the advanced quantitative techniques for establishing a statistical causeand-effect link in a theoretically supported network of relationships (Hoyle, 2012). In the two-stage structural equation modeling, the measurement model is tested first. It is expected to be tested and confirmed whether the observed variables that will form latent variables in the measurement model contribute significantly to the latent variables and whether the relationships between the latent variables and the direction of each other are meaningful are tested and expected to be verified (Kline, 2011). In the second phase of structural equation modeling, there is a test of the structural model created based on the theoretical infrastructure. In the structural model, pathways are established to reveal the statistical cause-effect relationship and the significance of the pathways and the goodness-of-fit indices of the model are examined. In order to determine the goodness of fit indexes in the analysis for structural equation modeling in the study, chi-square to the degree of freedom ratio $(\chi 2 / \mathrm{df})$, Root Mean Square Error of Approximation (RMSEA), Standardized Root Mean Square (SRMR), Goodness of Fit Index (GFI), Adjustment Goodness of Fit Index (AGFI) Incremental Fit Index (IFI) ve Comparative Fit Index (CFI) were taken into consideration (Brown, 2006; Meydan \& Şeşen, 2015). For structural equation modeling, the calculated ratio of $\chi^{2} / \mathrm{df}$ being lower than 3 indicates that the model has a good fit and lower than 5 indicates that it has an acceptable fit (Kline, 2011). Similarly, GFI, AGFI, IFI, and CFI values being higher than .90 and RMSEA and SRMR values being less than .08 are considered as an indicator of a compatible data model (Meydan \& Şeşen, 2015; Schumacker \& Lomax, 2010). The goodness of fit indices presented above was taken into consideration in the present study. In addition, in the case of measurement of latent variables with observed variables in structural equation modeling, a commonly used item, the parceling technique was used in order to reduce the number of variables observed in the model, to achieve a 
more normal distribution and increase reliability (Bandalos, 2008; Nasser-Abu Alhija \& Wisenbaker, 2006). Three sub-dimensions have been created for perceived stress and school satisfaction by item parceling technique. Friends, teachers, and school sub-dimensions on the school attachment scale are included in the analysis in their current state. The correlation values between the latent variables of the study are presented in Table 1 and the correlation values of the observed variables are presented in Table 2 . The study also carried out bootstrapping with structural equation modeling to provide additional evidence of whether the mediation was meaningful (Preacher \& Hayes, 2008). This process increases the number of samples and tests the significance of the direct and indirect effects in the established model and its use is increasing in mediation models day by day (MacKinnon, 2008). IBM SPSS and AMOS Graphics programs were used to carry out the analysis in this study.

\section{Results}

Correlations between latent and observed variables are presented in this section of the study. It was then tested with the structural equality model whether there was a mediating role of school attachment in the relationship between perceived stress and school satisfaction.

\section{Descriptive statistics}

In this study, some correlation values have negligible or low relationships, while others have substantial or high relationships. IBM SPSS and AMOS Graphics programs interpret whether the correlation values are significant or not significant according to the levels of 0.01 and 0.05 (Arbuckle, 2007). Given the inter-variable correlations presented in Table 1, it is observed that perceived stress has a negative and low relationship with school satisfaction $(r=-.27, p<.01)$ and school attachment $(r=-.28, p<.01)$. In addition, this study found a positive and high relationship between school satisfaction and school attachment $(r=.63, p<.01)$. 
Table 1. Correlation Values Between Latent Variables of the Research

\begin{tabular}{lllllllll}
\hline Variables & $\mathbf{1}$ & $\mathbf{2}$ & $\mathbf{3}$ & $\overline{\mathbf{X}}$ & $\boldsymbol{S D}$ & Skew. & Kurt. & $\boldsymbol{\alpha}$ \\
\hline 1. Perceived Stress & 1 & & & 16.24 & 5.12 & .84 & .21 & .80 \\
2. School Satisfaction & $-.27^{* *}$ & 1 & & 40.35 & 7.44 & -1.11 & .79 & .88 \\
3. School Attachment & $-.28^{* *}$ & $.63^{* *}$ & 1 & 57.97 & 6.91 & -1.19 & 1.26 & .88 \\
\hline
\end{tabular}
$* * p<.01$

Given the analysis results in Table 2, it has been found negligible, low, substantial or high relationships for observed variables. Table 2. Correlation Values among the Observed Variables of the Study

\begin{tabular}{|c|c|c|c|c|c|c|c|c|c|}
\hline Variables & 1 & 2 & 3 & 4 & 5 & 6 & 7 & 8 & 9 \\
\hline 1. PSP1 & 1 & & & & & & & & \\
\hline 2. PSP2 & $.56^{* *}$ & 1 & & & & & & & \\
\hline 3. PSP3 & $.54 * *$ & $.61 * *$ & 1 & & & & & & \\
\hline 4. SSP1 & $.20 * *$ & $\begin{array}{l}- \\
.24 * *\end{array}$ & $\begin{array}{l}- \\
.25^{* *}\end{array}$ & 1 & & & & & \\
\hline 5. SSP2 & $-28 * *$ & $-27 * *$ & $.29 * *$ & $.70 * *$ & 1 & & & & \\
\hline 6. SSP3 & $.16^{* *}$ & $.21 * *$ & $-19 * *$ & $.71 * *$ & $.73 * *$ & 1 & & & \\
\hline 7. SASD & $-25^{* *}$ & $-28 * *$ & $.26 * *$ & $.50 * *$ & $.58 * *$ & $.53 * *$ & 1 & & \\
\hline 8. FASD & $-.11 *$ & $\begin{array}{l}- \\
.15^{* *}\end{array}$ & $\begin{array}{l}- \\
.14 * *\end{array}$ & $.31 * *$ & $.34 * *$ & $.27^{* *}$ & $.52 * *$ & 1 & \\
\hline 9. TASD & $\begin{array}{l}- \\
.22 * * \\
\end{array}$ & $\begin{array}{l}- \\
.20 * * \\
\end{array}$ & $-23 * *$ & $.52 * *$ & $.51 * *$ & $.55^{* *}$ & $.66^{* *}$ & $.37 * *$ & 1 \\
\hline
\end{tabular}

** $p<.01 \quad$ PSP1-2-3(Perceived Stress Parcel 1-2-3) SSP 1-2-3 (School Satisfaction Parcel 1-2-3) SASD (School Attachment Sub-Dimension), FASD (Friend Attachment Sub-Dimension) TASD (Teacher Attachment SubDimension) 


\section{Measurement Model}

The measurement model was tested in the first phase of structural equation modeling. There are three latent variables and 9 observed variables that make up these latent variables in the measurement model. As a result of the measuring model, it was understood that all the path coefficients were significant and the factor loads ranged from .55 to .88. According to the goodness of fit indices $(\chi 2 / \mathrm{df}=2.51, p<.001, \mathrm{RMSEA}=.05, \mathrm{SRMR}=.03$, $\mathrm{GFI}=.98, \mathrm{AGFI}=.95, \mathrm{IFI}=.98, \mathrm{CFI}=.98)$, the measurement model seems to fit well. After verification of the measurement model, the structural model has been tested.

\section{Test of the Structural Model}

Baron and Kenny (1986) indicate that in order to test the mediator variable with the structural equation model, there must be a significant correlation between dependent (school satisfaction), independent (stress), and mediator (school attachment) variables. As shown in Table 1, there are meaningful relationships between stress, school satisfaction, and school attachment. In addition, when the findings in Table 2 are examined, it is observed that the observed variables formed by the parceling method have different levels of relationships among themselves, and the situation provides the basic conditions put forward by Baron and Kenny (1986). In summary, given the findings in Table 1 and Table 2, it can be said that the results reached are in line with the structural equation analysis. The structural equation model combines two different models, namely the measurement model, and the structural model. According to the two-stage approach, relations between variables must first be verified with the measurement model and then transition to the structural model (Şimşek, 2007). In this study, after the verification of the measurement model, the structural model was tested. In mediation analysis, the gender variable is incorporated into the structural model as the control variable. The results were found to have acceptable fit indices according to the structural equation model analysis, $(\chi 2 / \mathrm{df}=2.25, p$ $<.001, \mathrm{RMSEA}=.05, \mathrm{SRMR}=.03, \mathrm{GFI}=.98, \mathrm{AGFI}=.96, \mathrm{IFI}=.98, \mathrm{CFI}=$ .98). The structural model for the analysis is presented in Figure 1. As a result of the analysis, stress was found to negatively predict the school attachment $(\beta=-.36, p<.01)$ while school attachment positively predicts school satisfaction $(\beta=.72, p<.01)$. With the inclusion of school attachment as an intermediary variable in the model, the power of stress to predict school satisfaction $(\beta=-.06, p>.01)$ decreased. In other words, stress predicts school satisfaction at a significant level $(\beta=-.26, p<.01)$ over school attachment. It was seen that the gender included in the analysis as a control variable did not have a significant effect on the mediator $(\beta=.05, p>.05)$ and dependent $(\beta=$ $-.03, p>.05)$ variable. 


\section{Bootstrapping Process}

The significance of the direct and indirect effects of the variables in the model was examined by Bootstrap analysis and 2000 number, which was recommended in the literature (Arbuckle, 2007), was entered for the number of repeated samples. The coefficients of direct and indirect pathways resulting from Bootstrap analysis and the average effects of $95 \%$ confidence intervals for these coefficients are presented in Table 3. Accordingly, it can be stated that all direct pathway coefficients are significant. It is observed that the indirect pathway coefficient that allows the mediator role to be understood is also significant $(\beta=-.26, p<.01)$. In light of these results, it can be said that the relationship between perceived stress and school satisfaction in secondary school students has a full mediating role.

Table 3. Bootstrapping Process for the Fully Mediated Model

\begin{tabular}{|c|c|c|c|c|}
\hline \multicolumn{2}{|c|}{ Model Pathways } & \multicolumn{3}{|c|}{$\% 95 \mathrm{CI}$} \\
\hline \multicolumn{2}{|c|}{ Direct Effect } & Coefficient & Lower & Upper \\
\hline \multicolumn{2}{|c|}{ Stress $\rightarrow$ School Satisfaction } & $-.32 * *$ & -.41 & -.22 \\
\hline \multicolumn{2}{|c|}{ Stress $\rightarrow$ School Attachment } & $-.36 * *$ & -.46 & -.26 \\
\hline $\begin{array}{l}\text { School } \\
\text { Satisfaction }\end{array}$ & Attachment $\rightarrow$ School & $.72 * *$ & .62 & .82 \\
\hline \multicolumn{5}{|l|}{ Indirect Effect } \\
\hline $\begin{array}{l}\text { Stress } \rightarrow \text { School } \\
\text { Satisfaction }\end{array}$ & Attachment $\rightarrow$ School & $-.26 * *$ & -.35 & -.18 \\
\hline
\end{tabular}




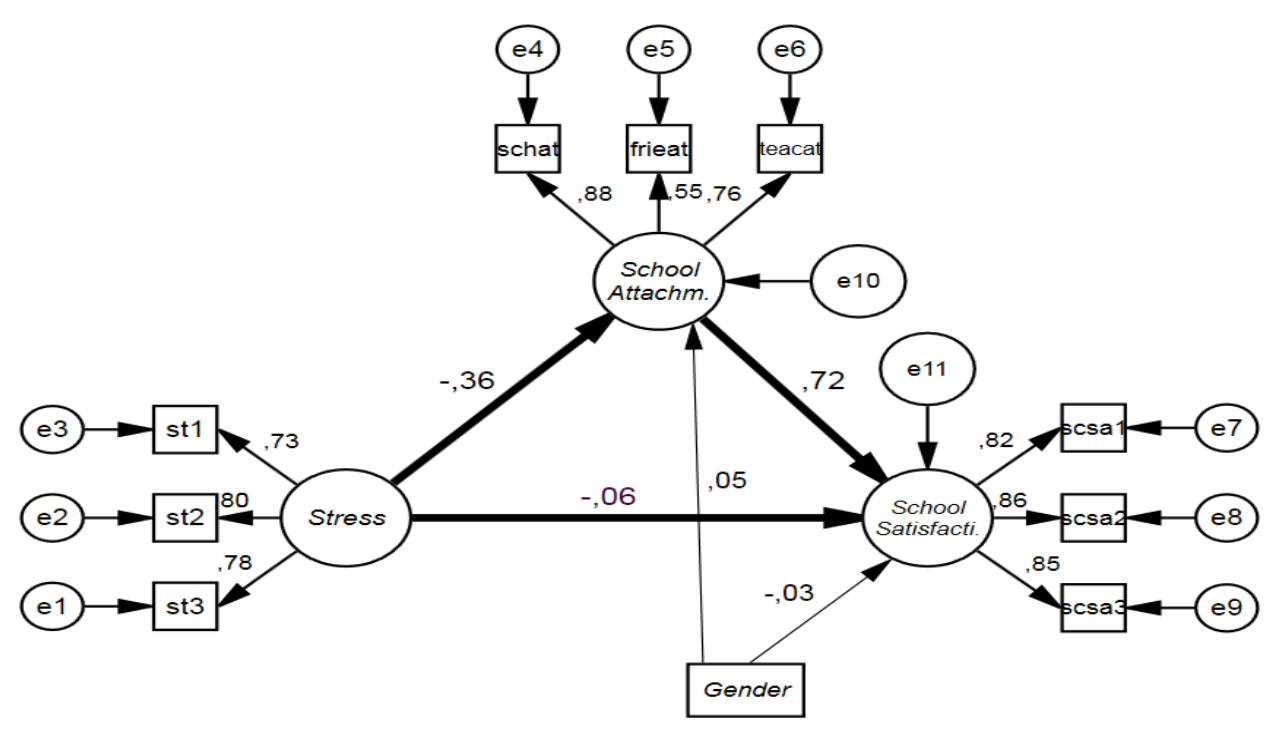

Figure 1. The Full Mediating Role of School Attachment between Perceived Stress and School Satisfaction

\section{Discussion}

In this study, whether or not school attachment has a mediating role in the relationship between secondary school students' stress and school satisfaction was examined by the structural equation model. Accordingly, it has been revealed that school attachment has a full mediating role between stress and school satisfaction. In other words, the high predictability of stress to school satisfaction has disappeared when the school attachment, which is the mediator variable, is included in the structural equation model. This result is discussed below in the light of theoretical and empirical data. Step-by-step evaluation of the model covered in the research is thought to be important. From here, in the order given in Table 3, first direct effects and then indirect effects will be discussed.

Although, the concept of stress which is defined as the negative emotions and beliefs that a person experiences when they feel unable to cope with the wishes of the environment they are in (Aronson et al., 2012), was expected to negatively predict the school satisfaction, which is defined as thinking that the positive and psychological needs of the self are met when evaluating the school environment, it is still an important finding. Thus, according to Longo (2000), middle school students stay away from activities and feel unhappiness when they perceive stress in the environment. According to O'rourke and Worzbyt (1996), students who experience stress have problems focusing on school and have concerns about school. In such a situation, it can be estimated that the student's school satisfaction will 
decrease. In addition, according to Fryxell (2000), students are in situations that can create anxiety in many areas at school. The concept of stress is positively correlated with anxiety, which in the literature is considered a variable that negatively affects an individual's psychological health (Lovibond \& Lovibond, 1995). Stress that occurs as a result of excessive tension, inability to relax due to overstimulation, threatening, and enforcing physical and spiritual boundaries, makes it difficult for the individual to adapt to the environment they are in (Baltaş \& Baltaş, 2012). Based on this, it can be said that stress is a variable that reduces the individual's school satisfaction. In light of this information, Lardier, Lee, Rodas, Reid, and Reid's (2020) study found a negative correlation between stress and school satisfaction among college students. In addition, Karatzias et al.'s (2002) study that was consisted of 425 secondary school students showed a negative correlation between students' stress levels and school satisfaction. In their study with adolescents, Huebner and McCullough (2000) stated that stress-inducing negative events reduced school satisfaction. When the studies mentioned in the literature are evaluated in a holistic way, it is thought that the finding that stress predicts school satisfaction negatively in this study is consistent and plausible.

School attachment which is another variable that stress predicts negatively is expressed as the students' feeling of belonging to their school, being proud of their school, and feeling safe in their school (Maddox \& Prinz, 2003). In order for the individual to have an attachment to the school, he/she must communicate with school-related elements (teachers, friends, etc.), make and receive signals, trust the school, and strive to explore his/her environment freely by meeting his/her needs (Howes, 1999). It is thought that it is difficult for a student with high levels of stress to go through such a life. Because stress is a condition that makes it difficult for the individual to adapt to their environment as a result of the threat of physical and spiritual boundaries (Baltaş \& Baltaş, 2012). It does not seem possible for a student who feels threatened to have confidence in the school and meet their psychological needs in the school. Also, according to Bowlby (1973), children are able to cope with stressful situations and make healthy decisions in terms of their own development when they think they are in an environment where they can have confidence. In contrast to this situation, however, they might have difficulty coping with stressful situations and has attachment problems. In addition, some children are more likely to experience stress at school due to problems in the family economy and apathy of parents. Given that children's reactions to stress and coping levels are different compared to adults (Terzian et al., 2010), children experiencing stress in a school environment where they do not feel safe and have difficulty coping with it can negatively affect school attachment. As such, according to the study of Ihtiyaroğlu and Ateş (2018) with students in adolescence, the level of school attachment decreases as the 
level of stress coping decreases. In addition, McGraw, Moore, Fuller and Bates (2008)'s study with secondary school students found that students with high levels of stress had low levels of attachment to friends and school. Another similar study shows an increase in school attachment and social interaction levels as stress levels decrease (Bergin \& Bergin, 2009). The results of the theoretical and empirical research were consistent with the finding that stress arising in the scope of this study negatively predicts school attachment.

The concept of school attachment an important concept that reinforces the individual's sense of belonging to the school and ensures that they are satisfied with school life (Ueno, 2009). While students with low levels of school attachment show school anger, students with high levels of school attachment show increased positive social behavior and psychological resilience (Ashley et al., 2012; Savi-Çakar \& Karataş, 2017). With school attachment, it is reported that students' loneliness and psychological distress decreases, while their positive emotions and school satisfaction increase (Baker et al., 2003; Katja et al., 2002; Tian et al., 2013). Another of the variables that can increase the school satisfaction of the student is that their friends and teachers at school offering social support to the student (Jiang, Huebner \& Siddall, 2013). From this point of view, as a result of this research, the fact that friends and teacher attachment, which is the sub-dimension of school attachment, increases school satisfaction, is consistent with the literature. In addition, it is expected that the students will be more willing to perform their duties in the school due to the school satisfaction that will occur with attachment to the school, and this will also strengthen their academic competence by increasing their motivation (Samdal et al., 1998). Proper and adequate satisfaction of students' need for attachment is considered extremely important in terms of physical, emotional, behavioral, and mental well-being (Osterman, 2000). School attachment also positively affects attitudes, perceptions, interests, and emotions towards the school and increases participation in academic activities within the school (Bouffard \& Couture, 2003; DeBacker \& Nelson, 2000). A study conducted with secondary school students in Turkey found that as the level of school attachment increases, school satisfaction also increases (Sağam \& Kaplanc1, 2018). Accordingly, it can be said that the scientific research and explanations made in the past are in harmony with the result of the present study which suggests that school attachment positively predicts school satisfaction.

The latest finding in the model identified in this research and the basis of the study is that the school attachment has a full mediating role in the relationship between stress and school satisfaction $\mathrm{n}$ the secondary school students. When the literature is examined, it is stated that different variables can affect students' school satisfaction. Some of these variables are school 
climate, student's perception that they feel safe at school, and that they can get social support from their teachers and friends (Papsova, Valihorova \& Nabelkova, 2012; Siddall, Huebner \& Jiang, 2013). Based on this explanation, the network of relationships between stress, school attachment, and school satisfaction that emerged within the scope of the research was examined in more detail. When stress levels rise, students stay away from activities in the school environment and are unable to adapt to school, and have school-related concerns. This significantly reduces the school satisfaction of the students. In addition, students who experience stress have difficulty adapting to their environment as a result of threatening and straining physical and mental limits (Baltaş \& Baltaş, 2012). In this case, it can be said that stress in students is a variable that reduces school satisfaction. One of the concepts that can eliminate the effect of stress on reducing school satisfaction is school attachment which is defined as having a sense of belonging to the school, feeling proud of the school, and feeling confident in the school (Maddox \& Prinz, 2003). As a matter of fact, with school attachment, it is reported that students' loneliness and psychological distress decreases, while their positive emotions and school satisfaction increase. Current study results go beyond these direct effects between variables, revealing that school attachment has a full mediatory role between stress and school satisfaction. As secondary school students' levels of school attachment increase, the level of stress that negatively affects school satisfaction decreases. In light of all this information, it is thought that the model laid out in the scope of this research is acceptable.

\section{Limitations, Suggestions and Conclusion}

There are some limitations inherent in the current study examining the mediating role of school attachment between stress and school satisfaction of secondary school students. Defining these limitations can help provide recommendations for future research. First, this study used self-reported measurement tools to collect research data. It should be taken into account that the variables in the research can only be explained within the scope of the measurement tools, since the data was obtained through stuednts' selfreporting. To avoid this limitation in future research, different methods and techniques can be used in addition to self-reporting measurement tools, such as observations, interviews, and peer evaluation. The second limitation in the study is methodically due to the inability to establish the cause-and-effect bond fully. Although structural equation modeling is one of the most powerful techniques that can be used in quantitative methods, longitudinal and experimental studies are needed to better explain the cause-and-effect bond. The third limitation of the study is that the sample group consists only of secondary school students studying in Turkey. Therefore, new research needs 
to be conducted with a larger sample group from different countries in order to increase the generality of the results.

Despite the limitations expressed, the importance of the model established by this study should not be minimized. Thus, it can be said that this model is meaningful and valid model. The findings from this study can be used as a source for preventive psychological counseling and guidance programs. School counselors can develop appropriate activities and psychoeducation programs in schools to strengthen secondary school students' school attachment and help them develop more positive feelings and thoughts towards school. In addition, individual and group studies aimed at reducing stress levels and coping with stress conducted by school psychological counselors can contribute to increasing school satisfaction. $\mathrm{n}$ addition to these, school psychological counselors can provide information about the importance of these concepts to administrators and other teachers who work in their schools. Because this can be beneficial in increasing students' school attachment and school satisfaction levels.

In conclusion, this study is the first to empirically present a structural model for secondary school students studying in Turkey, in which the relationship between stress and school satisfaction is fully mediated by the concept of school attachment. Considering that there are approximately five million secondary school students studying in Turkey, this study will make an important contribution to the literature.

\section{References:}

1. American Psychological Association (APA) (2009). Stress in America survey. Available online at: http://www.apa.org/news/press/releases/stress/2009/signs-stress.pdf Retrieved March 1, 2020.

2. Arbuckle, J. L. (2007). Amos 16.0 user's guide. Chicago, IL: SPSS.

3. Aronson, E., Wilson, T. D., \& Akert, R. M. (2012). Social psychology. İstanbul: Kaknüs Publishing.

4. Ashley, K. E., Ennis, L. E., \& Owusu-Ansah, A. N. (2012). An exploration of middle school students' perceptions of personal adolescent wellness and their connectedness to school. International Journal of Social Science and Education, 2(1), 74-89.

5. Bacete, F. J. G., Perrin, G. M., Schneider, B. H., \& Blanchard, C. (2014). Effects of school on the well-being of children and adolescents. In A. Ben-Arieh, F. Casas, I. Frones, \& J. E. Korbin (Eds.), Handbook of Child Well-Being (pp. 1251-1305). Netherlands: Springer.

6. Baker, J. A., Dilly, L. J., Aupperlee, J. L. \& Patil, S. A. (2003). The developmental context of school satisfaction: Schools as 
psychologically healthy environments. School Psychology Quarterly, 18(2), 206-221.

7. Baltaş, A. \& Baltaş, Z. (2012). Stres ve başa çıkma yolları (29 ${ }^{\text {th }}$ ed.). İstanbul: Remzi Kitabevi.

8. Bandalos, D. L. (2008). Is parceling really necessary? A comparison of results from item parceling and categorical variable methodology. Structural Equation Modeling: A Multidisciplinary Journal, 15(2), 211-240.

9. Baron, R. M., \& Kenny, D. A. (1986). The moderator-mediator variable distinction in social psychological research: Conseptual, strategic and statistical considerations. Journal of Personality \& Social Psychology, 51(6), 1173-1182.

10. Bergin, C., \& Bergin, D. (2009). Attachment in the classroom. Education Psychology Review, 21(2), 141-170.

11. Bouffard, T. \& Couture, N. (2003). Motivational profile and academic achievement among students enrolled in different schooling tracks. Educational Studies, 29(1), 19-38.

12. Bowlby, J. (1969). Attachment. Vol. 1: Attachment and loss. New York, NY: Basic Books.

13. Bowlby, J. (1973). Attachment Vol. 2: Separation, anxiety and anger. New York, NY: Basic Books.

14. Brown, T. A. (2006). Confirmatory factor analysis for applied research. New York, NY: Guilford Press.

15. Catalano, R., Haggerty, K., Oesterle, S., Fleming, C. \& Hawkins, J. (2004). The importance of bonding to school for healthy development: Findings from the social development research group. Journal of School Health, 74(7), 252-261.

16. DeBacker, T. K. \& Nelson, R. (2000). Motivation to learn science: Differences related to gender, class type, and ability. Journal of Educational Research, 93(4), 245-254.

17. DeSantis-King, A., Huebner, E. S., Suldo, S. M., \& Valois, R. F. (2006). An ecological view of school satisfaction in adolescence: Linkages between social support and behavior problems. Applied Research in Quality of Life, 1(3), 279-295.

18. Fredricks, J. A., Blumenfeld, P. C. \& Paris, A. H. (2004). School engagement: Potential of the concept, state of the evidence. Review of Educational Research, 74(1), 59-109.

19. Fryxell, D. (2000). Personal, social and family characteristics of angry students. Professional School Counseling, 4(2), 86-94.

20. Hampden-Thompson, G., \& Galindo, C. (2017). School-family relationships, school satisfaction and the academic achievement of young people. Educational Review, 69(2), 248-265. 
21. Hill, L. G., \& Werner, N. E. (2006). Affiliative motivation, school attachment, and aggression in school. Psychology in the Schools, 43(2), 231-246.

22. Hiloğlu, S., \& Cenkseven-Önder, F. (2010). The role of social skills and life satisfaction in predicting bullying among middle school students. Elementary Education Online, 9(3), 1159-1173.

23. Howes, C. (1999). Attachment relationships in the context of multiple caregivers. In J. Cassidy \& P. R. Shaver (Eds.) Handbook of attachment theory, research, and clinical applications (pp. 671-687). New York, NY: Guilford Press.

24. Hoyle, R. H. (2012). Handbook of structural equation modeling. New York, NY: Guilford Press.

25. Huebner, S. (2010). Students and schooling: Does happiness matter? NASP Communique 39(2), 6-8.

26. Huebner, E. S., Drane, W., \& Valois, R. F. (2000). Levels and demographic correlates of adolescent life satisfaction reports. School Psychology International, 21(3), 281-292.

27. Huebner, E. S., \& Gilman, R. (2006). Students who like and dislike school. Applied Research in Quality of Life, 1(2), 139-150.

28. Huebner, E. S., \& McCullough, G. (2000). Correlates of school satisfaction among adolescents. The Journal of Educational Research, 93(5), 331-335.

29. İhtiyaroğlu, N. \& Ateş, Ö. T. (2018). Analyzing the relationship between the students' stres-coping styles and school attachment. Asian Journal of Education and Training, 4(4), 371-379.

30. Jiang, X., Huebner, E. S., \& Siddall, J. (2013). A short-term longitudinal study of differential sources of school-related social support and adolescents' school satisfaction. Social Indicators Research, 114(3), 1073-1086.

31. Karatzias, T., Power, K. G., Flemming, J., Lennan, F., \& Swanson, V. (2002). The role of demographics, personality variables and school stress on predicting school satisfaction/dissatisfaction: Review of the literature and research findings. Educational Psychology, 22(1), 33-50.

32. Katja, R., Paivi, A. K., Marja-Terttu, T., \& Pekka, L. (2002). Relationships among adolescent subjective well-being, health behavior, and school satisfaction. Journal of School Health, 72(6), 243-249.

33. Kline, R. B. (2011). Principles and practices of structural equation modeling. New York, NY: Guilford Press.

34. Klingman, A. (2006). Children and war trauma. In W. Damon, R. M. Lerner, K. A. Renninger, \& I. E. Sigel (Eds.), Handbook of child psychology (pp. 619-652). Hoboken, NJ: John Wiley \& Sons. 
35. Korkut-Owen, F. (2015). Okul temelli önleyici rehberlik ve psikolojik danışma. Ankara: Anı Publishing.

36. Lardier, D. T., Lee, C.Y.S., Rodas, J.M., Reid, P.G., \& Reid, R.J. (2020). The effect of perceived college-related stres on depression, life satisfaction, and school satisfaction: The coping strategies of hispanic college students from a hispanic serving institution. Education and Urban Society, (in press)

37. Levitt, P. (2014). Toxic stress and its impact on early learning and health: Building a formula for human capital development. In $\mathrm{K}$. Bogenschneider \& O. Little (Eds.), The science of early brain development: A foundation for the success of our children and the state economy (pp. 9-21). Madison, WI: Wisconsin Family Impact Seminars, University of Wisconsin.

38. Longo, M. F. (2000). Lightening the load for the pressured child. The Education Digest, 66(1), 47-49.

39. Lovibond, P. F., \& Lovibond, S. H. (1995). The structure of negative emotional states: Comparison of the Depression Anxiety Stress Scales (DASS) with the Beck Depression and Anxiety Inventories. Behaviour Research and Therapy, 33(3), 335-343.

40. MacKinnon, D. P. (2008). Introduction to statistical mediation analysis, multivariate applications series. New York, NY: Taylor \& Francis Group.

41. Maddox, S. J., \& Prinz, R. J. (2003). School bonding in children and adolescents: Conceptualization, assessment, and associated variables. Clinical Child and Family Psychology Review, 6(1), 31-49.

42. McGraw, K., Moore, S., Fuller, A., \& Bates, G. (2008). Family, peer and school connectedness in final year secondary school students. Australian Psychologist, 43(1), 27-37.

43. Meydan, C.H., \& Şeşen, H. (2015). Yapısal eşitlik modellemesi AMOS uygulamaları. Ankara: Detay Yayıncılik.

44. Middlebrooks, J. S., \& Audage, N. C. (2008). The effects of childhood stress on health across the lifespan. Atlanta, GA: Centers for Disease Control and Prevention.

45. Morgan, G. A., Leech, N. L., Gloeckner, G. W., \& Barrett, K. C. (2004). Spss for introductory statistics: Use and interpretation. New York, NY: Psychology Press.

46. Nasser-Abu Alhija, F., \& Wisenbaker, J. (2006). A Monte Carlo study investigating the impact of item parceling strategies on parameter estimates and their standard errors in CFA. Structural Equation Modeling, 13(2), 204-228.

47. Nielsen, S. K. K., Lonfeldt, N., Wolitzky-Taylor, K. B., Hageman, I., Vangkilde, S., \& Daniel, S. I. F. (2017). Adult attachment style and 
anxiety - the mediating role of emotion regulation. Journal of Affective Disorders, 218, 253-259.

48. Oral, T., \& Ersan, C. (2017). Çocuklarda (8-11 yaş) algılanan stress ölçeği’nin Türkçeye uyarlama çalışması. Selçuk Üniversitesi Edebiyat Fakültesi Dergisi (SEFAD), 37, 419-428.

49. O’Rourke, K., \& Worzbyt, J.C. (1996). Support groups for children. Washington, DC: Accelerated Development - A member of Taylor and Francis.

50. Osterman, K. F. (2000). Students' need for belonging in the school community. Review of Educational Research, 70(3), 323-367.

51. Özdemir, Y., \& Koruklu, N. (2013). Parental attachment, school attachment and life satisfaction in early adolescence. Elementary Education Online, 12(3), 836-848.

52. Özdemir, Y. \& Sağkal, A. S. (2016). Turkish adaptation of brief adolescents' subjective well-being in school scale (BASWBSS): Validity and reliability study. Ege Education Journal, 17(2), 333-350.

53. Papsova, M., Valihorova, M., \& Nabelkova, E. (2012). Exploring the moderating effect of field dependence-independence on relationship between pupil's school satisfaction and social classroom atmosphere. Studia Psychologica, 54(2), 125-136.

54. Preacher, K. J. \& Hayes, A. F. (2008). Asymptotic and resampling strategies for assessing and comparing indirect effects in multiple mediator models. Behavior Research Methods, 40(3), 879-891.

55. Proctor, C., Linley, P. A., \& Maltby, J. (2010). Very happy youths: Benefits of very high life satisfaction among adolescents. Social Indicators Research, 98(3), 519-532.

56. Saarni, C. (1999). Development of emotional competence. New York, NY: Guilford Press.

57. Sağlam, H. İ., \& Kaplancı, B. (2018). Examining the sense of responsibility of the primary school students in terms of school satisfaction and school attachment. Journal of Family, Counseling and Education, 3(1), 1-16.

58. Samdal, O., Nutbeam, D., Wold, B., \& Kannas, L. (1998). Achieving health and educational goals through schools: A study of the importance of the school climate and the students' satisfaction with school. Health Education Research, 13(3), 383-397.

59. Santrock, J. W. (2012). Adolescence (14 ${ }^{\text {th }}$ Edition). New York, NY: McGraw-Hill Education.

60. Savi, F. (2011). School attachment scale for children and adolescents: The study of validity and reliability. Elementary Education Online, 10(1), 80-90. 
61. Savi-Çakar, F., \& Karataş, Z. (2017). Adolescents’ self-esteem, school anger and life satisfaction as predictors of their school attachment. Education and Science, 42(189), 121-136.

62. Schnettler, B., Orellana, L., Lobos, G., Miranda, H., Sepulveda, J., Etchebarne, S., .. \& \& Grunert, K. G. (2015). Relationship between the domains of the multidimensional students' life satisfaction scale, satisfaction with food-related life and happiness in university students. Nutricion Hospitalaria, 31(6), 2752-2763.

63. Schumacker, R.E., \& Lomax, R.G. (2010). A beginner's guide to structural equation modeling (3th ed.). New York, NY: Routledge.

64. Siddall, J., Huebner, E. S., \& Jiang, X. (2013). A prospective study of differential sources of school-related social support and adolescent global life satisfaction. American Journal of Orthopsychiatry, 83(1), 107-114.

65. Snoeren, F., \& Hoefnagels, C. (2014). Measuring perceived social support and perceived stress among primary school children in the Netherlands. Child Indicators Research, 7(3), 473-486.

66. Suldo, S., Riley, K., \& Shaffer, E. (2006). Academic correlates of children and adolescents' life satisfaction. School Psychology International, 27(5), 567-582.

67. Şimşek, Ö. F. (2007). Yapısal eşitlik modellemesine giriş temel ilkeler ve LISREL uygulamalart. Ankara: Ekinoks.

68. Terzian, M., Moore, K. A., \& Nguyen, H. N. (2010). Assessing stress in children and youth: A guide for out of school time program practitioners. Child Trends, 22, 1-5.

69. Thompson, R. A. (2014). Stress and child development. The Future of Children 24(1), 41-59.

70. Tian, L., Liu, B., Huang, S., \& Huebner, E. S. (2013). Perceived social support and school well-being among Chinese early and middle adolescents: The meditational role of self-esteem. Social Indicators Research, 113(3), 991-1008.

71. Tian, L., Wang, D., \& Huebner, E. S. (2015). Development and validation of the brief adolescents' subjective well-being in school scale (BASWBSS). Social Indicators Research, 120(2), 615-634.

72. Ueno, K. (2009). Same-race friendships and school attachment: Demonstrating the interaction between personal network and school composition. Sociological Forum, 24(3), 515-537.

73. Uluğ, M. (2010). Stress. İstanbul: İstanbul Kültür University Publishing.

74. Varela, J. J., Zimmerman, M. A., Ryan, A. M., Stoddard, S. A., Heinze, J. E., \& Alfaro, J. (2018). Life satisfaction, school satisfaction, and 
school violence: A mediation analysis for Chilean adolescent victims and perpetrators. Child Indicators Research, 11(2), 487-505. 